\author{
Correspondence \\ Wen-Jun Li \\ wjli@ynu.edu.cn \\ Dayanand Agasar \\ iamdaya62@rediffmail.com
}

\section{Saccharomonospora saliphila sp. nov., a halophilic actinomycete from an Indian soil}

\author{
Dastager G. Syed, ${ }^{1,2}$ Shu-Kun Tang, ${ }^{1}$ Man Cai, ${ }^{1}$ Xiao-Yang Zhi, ${ }^{1}$ \\ Dayanand Agasar, ${ }^{2}$ Jae-Chan Lee, ${ }^{3}$ Chang-Jin Kim, ${ }^{3}$ Cheng-Lin Jiang, ${ }^{1}$ \\ Li-Hua $\mathrm{Xu}^{1}$ and Wen-Jun Li ${ }^{1}$
${ }^{1}$ The Key Laboratory for Microbial Resources of the Ministry of Education, PR China, and Laboratory for Conservation and Utilization of Bio-Resources, Yunnan Institute of Microbiology, Yunnan University, Kunming 650091, PR China
${ }^{2}$ Department of Studies and Research in Microbiology, Gulbarga University, Gulbarga - 585 106, Karnataka, India \\ ${ }^{3}$ Functional Metabolomics Research Center, KRIBB, Daejeon 305-806, Korea
}

Nonomura \& Ohara (1971) described the genus Saccharomonospora in the actinomycete family Pseudonocardiaceae for organisms that produce predominantly single spores, and occasionally spores in pairs and short chains, on aerial hyphae. Members of the genus contain meso-diaminopimelic acid together with the sugars arabinose and galactose. To date, seven species with validly published names are described in the genus: Saccharomonospora viridis Nonomura and Ohara 1971, Saccharomonospora azurea $\mathrm{Hu}$ 1987, Saccharomonospora

The GenBank/EMBL/DDBJ accession number for the $16 \mathrm{~S}$ rRNA gene sequence of strain YIM $90502^{\top}$ is DQ367416.

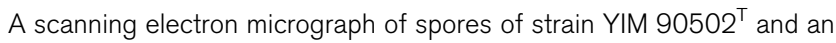
extended 16S rRNA gene sequence-based phylogenetic tree are available as supplementary material with the online version of this paper. glauca Greiner-Mai et al. 1988, Saccharomonospora cyanea $\mathrm{Hu}$ et al. 1988, Saccharomonospora xinjiangensis Jin et al. 1998, Saccharomonospora halophila Al-Zarban et al. 2002 and Saccharomonospora paurometabolica Li et al. 2003. Of these, only the last two are halophilic. During a study on halophilic actinomycetes, a halophilic strain YIM $90502^{\mathrm{T}}$ was isolated from a sample of muddy soil from Gulbarga, Karnataka Province, in the southern part of India. This is the first report of a Saccharomonospora species from Indian soil.

Strain YIM $90502^{\mathrm{T}}$ was isolated by using modified glycerol/ asparagine agar (Shirling \& Gottlieb, 1966) [International Streptomyces Project medium 5 (ISP 5) containing $20 \%$ $(\mathrm{w} / \mathrm{v}) \mathrm{NaCl}$ ] and incubated at $28{ }^{\circ} \mathrm{C}$ for about 4 weeks. The strain was maintained on yeast extract/malt extract (ISP 2) 
and ISP 5 agar slants containing $10 \% \mathrm{NaCl}$ at $4{ }^{\circ} \mathrm{C}$ and as glycerol suspensions $(20 \%, \mathrm{v} / \mathrm{v})$ at $-80{ }^{\circ} \mathrm{C}$. Biomass for chemical and molecular systematic studies was obtained by growing in shake flasks (about 150 r.p.m.) of ISP 2 broth medium containing $10 \% \mathrm{NaCl}$ at $28{ }^{\circ} \mathrm{C}$ for 1 week. Cultural characteristics were determined after 4 weeks at $28{ }^{\circ} \mathrm{C}$ by methods used in the ISP (Shirling \& Gottlieb, 1966), but all media were supplemented with $10 \% \mathrm{NaCl}$ $(\mathrm{w} / \mathrm{v})$. Morphological properties, spores and mycelia were examined by light microscopy (Olympus microscope $\mathrm{BH}-$ 2) and scanning electron microscopy (JEOL model JSM5600LV). Media and procedures used for determination of physiological features and carbon source utilization were those described by Shirling \& Gottlieb (1966) and Williams et al. (1989). Colour determination was done with colour chips from the ISCC-NBS Color Name Charts Standard Samples no. 2106 (Kelly, 1964). Strain YIM $90502^{\mathrm{T}}$ developed well on most media tested. No diffusible pigments were produced. The results are indicated in detail in the species description and in Table 1.

Morphological features were observed on ISP 5 and ISP 2 medium $[10 \%(\mathrm{w} / \mathrm{v}) \mathrm{NaCl}]$ incubated for 4 weeks at $28{ }^{\circ} \mathrm{C}$. Strain YIM $90502^{\mathrm{T}}$ had characteristics typical of the genus Saccharomonospora. Aerial mycelium and substrate mycelium were well developed. Smooth or wrinkled spores were produced on the branched aerial mycelium singly or in pairs (Supplementary Fig. S1, available in IJSEM Online).

Amino acid and sugar analysis of whole-cell hydrolysates was performed according to the procedures described by Staneck \& Roberts (1974). Polar lipids were extracted, examined by two-dimensional TLC and identified using published procedures (Minnikin et al., 1984). Menaquinones were extracted using the methods of Minnikin et al. (1984) and separated by HPLC (Kroppenstedt et al., 1981; Kroppenstedt, 1982). For fatty acid methyl ester analysis, cell mass was harvested from trypticase soy broth after incubation for 7 days at $28{ }^{\circ} \mathrm{C}$. The fatty acid methyl esters were extracted and prepared according to the standard protocol of the MIDI/Hewlett Packard Microbial Identification System (Sasser, 1990). The cell wall of strain YIM $90502^{\mathrm{T}}$ contained meso-diaminopimelic acid. Whole-cell hydrolysates contained mainly galactose and arabinose. The menaquinones were MK-9 $\left(\mathrm{H}_{4}\right)(90 \%)$ and MK-8 $\left(\mathrm{H}_{4}\right)(10 \%)$. The polar lipid extract contained phosphatidylinositol, phosphatidylglycerol, diphosphatidylglycerol and phosphatidylethanolamine. Major cellular fatty acids are indicated in detail in the species description.

Extraction of genomic DNA and amplification of the $16 \mathrm{~S}$ rRNA gene were done as described by Li et al. (2007). The almost-complete 16S rRNA gene sequence (1497 nt) of strain YIM $90502^{\mathrm{T}}$ was obtained (positions $29-1542$ in the

Table 1. Characteristics that differentiate strain YIM $90502^{\top}$ from type strains of other Saccharomonospora species

Strains: 1, YIM $90502^{\mathrm{T}}$; 2, S. halophila DSM $44411^{\mathrm{T}}$; 3, S. paurometabolica DSM 44619 ${ }^{\mathrm{T}}$;4, S. azurea KCTC $9693^{\mathrm{T}}$;5, S. cyanea NA-134 ${ }^{\mathrm{T}}$; 6, S. glauca DSM $43769^{\mathrm{T}}$; 7, S. viridis NCIB $9602^{\mathrm{T}}$; 8, S. xinjiangensis DSM $44391^{\mathrm{T}}$. + , Present; -, absent; D, doubtful; ND, no data available. Data for reference strains were taken from Al-Zarban et al. (2002) and Li et al. (2003).

\begin{tabular}{|c|c|c|c|c|c|c|c|c|}
\hline Characteristic & 1 & 2 & 3 & 4 & 5 & 6 & 7 & 8 \\
\hline \multicolumn{9}{|c|}{ Utilization of carbon sources $(1 \%, \mathrm{w} / \mathrm{v})$} \\
\hline L-Arabinose & - & + & - & - & + & + & - & ND \\
\hline Glucose & - & + & - & + & + & + & $\mathrm{D}$ & ND \\
\hline Mannitol & + & + & - & - & + & + & $\mathrm{D}$ & + \\
\hline Mannose & - & + & - & + & + & ND & - & + \\
\hline Melibiose & + & + & - & + & - & ND & ND & $\mathrm{ND}$ \\
\hline Rhamnose & + & + & - & - & - & - & - & + \\
\hline Xylose & + & - & - & + & + & + & - & + \\
\hline \multicolumn{9}{|l|}{ Growth in the presence of $\mathrm{NaCl}(\%)$ : } \\
\hline 10 & + & + & + & - & - & - & - & - \\
\hline 20 & + & + & + & - & - & - & - & - \\
\hline 30 & - & + & - & - & - & - & - & - \\
\hline Optimal growth temperature $\left({ }^{\circ} \mathrm{C}\right)$ & $28-30$ & $28-30$ & $35-37$ & $28-30$ & $28-30$ & $45-50$ & $45-50$ & $28-40$ \\
\hline
\end{tabular}


Escherichia coli numbering) and BLAST search comparisons were made against the GenBank/EMBL/DDBJ databases. Phylogenetic analysis was performed using software packages PHYLIP (Felsenstein, 1993) and MEGA version 2.1 (Kumar et al., 2001) following the multiple alignment of data using CLUSTAL_X (Thompson et al., 1997). Phylogenetic analysis was performed by using different treemaking algorithms, the neighbour-joining (Saitou \& Nei, 1987), maximum-likelihood (Felsenstein, 1981) and maximum-parsimony (Fitch, 1971) methods. Evolutionary distances (Kimura's two-parameter model; Kimura, 1980, 1983) and clustering were calculated with the neighbourjoining method of Saitou \& Nei (1987). The topology of the phylogenetic tree (Fig. 1) was evaluated by the bootstrap resampling method of Felsenstein (1985) with 1000 replicates. The highest similarity values were found with sequences of members of the genus Saccharomonospora: S. azurea KCTC $9693^{\mathrm{T}}(97.45 \%)$, S. halophila DSM $44411^{\mathrm{T}}(97.41 \%)$ and S. paurometabolica DSM $44619^{\mathrm{T}}(97.27 \%)$. A neighbour-joining tree showing the phylogenetic relationships between strain YIM $90502^{\mathrm{T}}$ and other members of the family Pseudonocardiaceae is shown in Supplementary Fig. S2.

DNA for renaturation studies and determination of the base content of strain YIM $90502^{\mathrm{T}}$ was prepared following the method of Marmur (1961). The G $+C$ content was determined using the thermal denaturation method of Marmur \& Doty (1962). DNA-DNA hybridization was carried out according to methods described by $\mathrm{He}$ et al. (2005). The $\mathrm{G}+\mathrm{C}$ content of the genomic DNA from strain YIM $90502^{\mathrm{T}}$ was $71.8 \mathrm{~mol} \%$. DNA-DNA reassociation between strain YIM $90502^{\mathrm{T}}$ and S. azurea KCTC $9693^{\mathrm{T}}$, S. halophila DSM $44411^{\mathrm{T}}$ and S. paurometabolica DSM $44619^{\mathrm{T}}$ indicated moderate values of $46.0,41.0$ and $42.5 \%$ (mean values, all repeated three times), respectively.

The phylogenetic distinctiveness and DNA-DNA relatedness data were sufficient to categorize strain YIM $90502^{\mathrm{T}}$ as

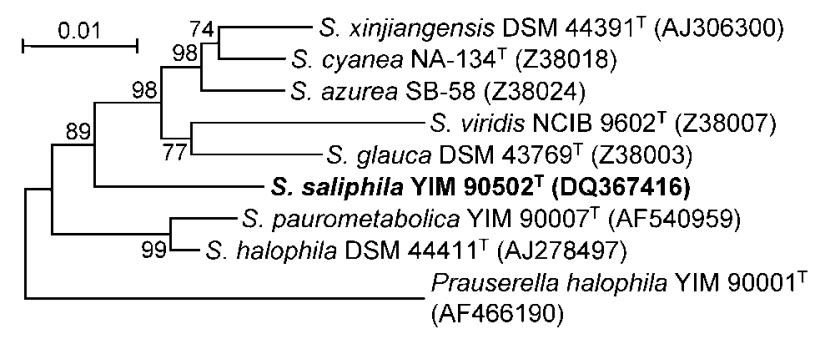

Fig. 1. Phylogenetic dendrogram obtained by distance matrix analysis of $16 \mathrm{~S}$ rRNA gene sequences, showing the position of strain YIM $90502^{\top}$ among its phylogenetic neighbours. Numbers at branch nodes are bootstrap values, expressed as percentages of 1000 replicates. The sequence of Prauserella halophila YIM $90001^{\top}$ was used as the root. Bar, $1 \%$ sequence divergence. An extended tree is available as Supplementary Fig. S2 in IJSEM Online. distinct from previously recognized Saccharomonospora species (Hu, 1987; Al-Zarban et al., 2002; Li et al., 2003) and it is supported by sufficient physiological and cultural differences from some phylogenetically related Saccharomonospora species (Table 1) to justify the description of a novel species, Saccharomonospora saliphila sp. nov.

\section{Description of Saccharomonospora saliphila sp. nov.}

Saccharomonospora saliphila (sa.li' phi.la. L. n. sal, salis salt; Gr. adj. philos loving; N.L. fem. adj. saliphila salt-loving).

Aerial mycelium is well developed on yeast extract/malt extract agar (ISP 2 medium), inorganic salts/starch agar (ISP 4 medium), glycerol/asparagine agar (ISP 5 medium), potato agar and Czapek's agar; no growth on oatmeal agar (ISP 3 medium) or nutrient agar. Greyish to reddish-grey aerial mycelium on all media tested. Sporulation is good on ISP 2, ISP 4, ISP 5, potato agar and Czapek's agar. Substrate mycelium is well developed on most test media. Colour is greyish red (Czapek's agar), dark red (ISP 2 and ISP 5) or blackish red (ISP 4 and potato agar). Non-motile single or paired spores with smooth or wrinkled surfaces are borne on aerial mycelium. Optimum growth temperature is $28{ }^{\circ} \mathrm{C}$; grows well up to $40{ }^{\circ} \mathrm{C}$. Optimum growth is observed at $10 \%(\mathrm{w} / \mathrm{v}) \mathrm{NaCl}$. Positive for $\mathrm{H}_{2} \mathrm{~S}$ production. Negative for milk peptonization and coagulation, gelatin liquefaction, growth in cellulose, melanin production, starch hydrolysis and urease production. The following carbon sources are utilized: cellobiose, D-galactose, Dglucose, D-xylose, fructose, maltose, raffinose, sorbitol and sucrose. L-Arabinose, myo-inositol, lactose, mannitol, rhamnose, trehalose and xylitol are not utilized. The cell wall contains meso-diaminopimelic acid. Whole-cell hydrolysates contain mainly galactose and arabinose. The menaquinones are $\mathrm{MK}-9\left(\mathrm{H}_{4}\right)(90 \%)$ and $\mathrm{MK}-8\left(\mathrm{H}_{4}\right)$ $(10 \%)$ and the phospholipids are phosphatidylinositol, phosphatidylglycerol, diphosphatidylglycerol and phosphatidylethanolamine. Major cellular fatty acids are iso- $\mathrm{C}_{16: 0}$ $(49.2 \%), \mathrm{C}_{17: 1} \omega 6 c(9.1 \%), \mathrm{C}_{15: 0}(5.42 \%)$ and iso- $\mathrm{C}_{16: 1}$ $\mathrm{OH}(5.02 \%)$. Fatty acids present in smaller amounts $(>1 \%)$ are iso- $\mathrm{C}_{15: 0}(1.45 \%), \mathrm{C}_{16: 0}(3.61 \%), 10$-methyl$\mathrm{C}_{16: 0}(2.51 \%)$, iso- $\mathrm{C}_{17: 0}(3.72 \%), \mathrm{C}_{17: 0}(3.67 \%)$ and iso$\mathrm{C}_{18: 0}(1.44 \%)$. The DNA G $+\mathrm{C}$ content of the type strain is $71.8 \mathrm{~mol} \%$.

The type strain is YIM $90502^{\mathrm{T}}\left(=\mathrm{KCTC} 19234^{\mathrm{T}}=\mathrm{DSM}\right.$ $45087^{\mathrm{T}}$ ), isolated from soil collected from Gulbarga, Karnataka Province, southern India.

\section{Acknowledgements}

This research was supported by the National Basic Research Program of China (no. 2004CB719601), the National Natural Science Foundation of China (nos 30560001 and 30600001) and the Yunnan Provincial International Cooperative Program (no. 2005GH21). W.-J.L. was also supported by the Program for New Century Excellent Talent in University (NCET). 


\section{References}

Al-Zarban, S. S., Al-Musallam, A. A., Abbas, I., Stackebrandt, E. \& Kroppenstedt, R. M. (2002). Saccharomonospora halophila sp. nov., a novel halophilic actinomycete isolated from marsh soil in Kuwait. Int J Syst Evol Microbiol 52, 555-558.

Felsenstein, J. (1981). Evolutionary trees from DNA sequences: a maximum likelihood approach. J Mol Evol 17, 368-376.

Felsenstein, J. (1985). Confidence limits on phylogenies: an approach using the bootstrap. Evolution 39, 783-791.

Felsenstein, J. (1993). PHYLIP (phylogeny inference package), version 3.5. Distributed by the author. Department of Genome Sciences, University of Washington, Seattle, USA.

Fitch, W. M. (1971). Toward defining the course of evolution: minimum change for a specific tree topology. Syst Zool 20, 406-416.

Greiner-Mai, E., Korn-Wendisch, F. \& Kutzner, H. J. (1988). Taxonomic revision of the genus Saccharomonospora and description of Saccharomonospora glauca sp. nov. Int J Syst Bacteriol 38, 398-405.

He, L., Li, W., Huang, Y., Wang, L., Liu, Z., Lanoot, B., Vancanneyt, M. \& Swings, J. (2005). Streptomyces jietaisiensis sp. nov., isolated from soil in northern China. Int J Syst Evol Microbiol 55, 1939-1944.

Hu, R. (1987). Saccharomonospora azurea sp. nov., a new species from soil. Int J Syst Bacteriol 37, 60-61.

Hu, R., Lin, C. \& Wei, G. (1988). Saccharomonospora cyanea sp. nov. Int J Syst Bacteriol 38, 444-446.

Jin, X., Xu, L.-H., Mao, P.-H., Hseu, T.-H. \& Jiang, C. L. (1998). Description of Saccharomonospora xinjiangensis sp. nov. based on chemical and molecular classification. Int J Syst Bacteriol 48, 1095-1099.

Kelly, K. L. (1964). Inter-Society Color Council-National Bureau of Standards Color Name Charts Illustrated with Centroid Colors. Washington, DC: US Government Printing Office.

Kimura, M. (1980). A simple method for estimating evolutionary rates of base substitutions through comparative studies of nucleotide sequences. J Mol Evol 16, 111-120.

Kimura, M. (1983). The Neutral Theory of Molecular Evolution. Cambridge: Cambridge University Press.

Kroppenstedt, R. M. (1982). Separation of bacterial menaquinones by HPLC using reverse phase (RP18) and a silver loaded ion exchanger as stationary phases. J Liq Chromatogr 5, 2359-2367.

Kroppenstedt, R. M., Korn-Wendisch, F., Fowler, V. J. \& Stackebrandt, E. (1981). Biochemical and molecular genetic evidence for transfer of Actinoplanes armeniacus into the family Streptomycetaceae. Zentralbl Bakteriol Mikrobiol Hyg 1 Abt Orig C 2, 254-262.
Kumar, S., Tamura, K., Jakobsen, I.-B. \& Nei, M. (2001). MEGA2: molecular evolutionary genetics analysis software. Bioinformatics $\mathbf{1 7}$, 1244-1245.

Li, W.-J., Tang, S.-K., Stackebrandt, E., Kroppenstedt, R. M., Schumann, P., Xu, L.-H. \& Jiang, C.-L. (2003). Saccharomonospora paurometabolica sp. nov., a moderately halophilic actinomycete isolated from soil in China. Int J Syst Evol Microbiol 53, 1591-1594.

Li, W.-J., Xu, P., Schumann, P., Zhang, Y.-Q., Pukall, R., Xu, L.-H., Stackebrandt, E. \& Jiang, C.-L. (2007). Georgenia ruanii sp. nov., a novel actinobacterium isolated from forest soil in Yunnan (China), and emended description of the genus Georgenia. Int J Syst Evol Microbiol 57, 1424-1428.

Marmur, J. (1961). A procedure for the isolation of deoxyribonucleic acid from microorganisms. J Mol Biol 3, 208-218.

Marmur, J. \& Doty, P. (1962). Determination of the base composition of deoxyribonucleic acid from its thermal denaturation temperature. J Mol Biol 5, 109-118.

Minnikin, D. E., O’Donnell, A. G., Goodfellow, M., Alderson, G., Athalye, M., Schaal, A. \& Parlett, J. H. (1984). An integrated procedure for the extraction of isoprenoid quinones and polar lipids. J Microbiol Methods 2, 233-241.

Nonomura, H. \& Ohara, Y. (1971). Distribution of actinomycetes in soil. X. New genus and species of monosporic actinomycetes in soil. J Ferment Technol 49, 895-903.

Saitou, N. \& Nei, M. (1987). The neighbor-joining method: a new method for reconstructing phylogenetic trees. Mol Biol Evol 4, 406-425.

Sasser, M. (1990). Identification of bacteria by gas chromatography of cellular fatty acids. USFCC Newsl 20, 16.

Shirling, E. B. \& Gottlieb, D. (1966). Methods for characterization of Streptomyces species. Int J Syst Bacteriol 16, 313-340.

Staneck, J. L. \& Roberts, G. D. (1974). Simplified approach to identification of aerobic actinomycetes by thin-layer chromatography. Appl Microbiol 28, 226-231.

Thompson, J. D., Gibson, T. J., Plewniak, F., Jeanmougin, F. \& Higgins, D. G. (1997). The CLUSTAL_X windows interface: flexible strategies for sequence alignment aided by quality analysis tools. Nucleic Acids Res 25, 4876-4882.

Williams, S. T., Goodfellow, M. \& Alderson, G. (1989). Genus Streptomyces Waksman and Henrici 1943, 339 ${ }^{\mathrm{AL}}$. In Bergey's Manual of Systematic Bacteriology, vol. 4, pp. 2452-2492. Edited by S. T. Williams, M. E. Sharpe \& J. G. Holt. Baltimore: Williams \& Wilkins. 